\title{
LEADERSHIP STYLE AND ORGANIZATIONAL COMMUNICATION PATTERNS: A QUALITATIVE DESCRIPTIVE STUDY
}

\author{
Alum Kusumah ${ }^{1^{*}}$, Khusnul Fikri \\ ${ }^{1,2}$ Faculty of Economic and Business, Universitas Muhammadiyah Riau, Indonesia \\ *Corresponding author: alumkusumah@gmail.com
}

\section{A R T I C L E I N F O}

Article History:

Received: 30 May 2021

Revised: 07 June 2021

Accepted: 21 June 2021

Keywords:

Leadership Style;

Organizational Communication;

Communication Patterns;

Qualitative Methods

\section{A B S T R A C T}

This study aims to examine the leadership style and organizational communication pattern in the Converting Department, PT. IPP. The leadership elements described are at the general manager and manager levels. The research method used is descriptive and qualitative methods. The data used are primary and secondary data collected through observation supported by interviews, library research, and document analysis. Data and information obtained from the employee of Converting Department, PT. IPP, with as many as 22 informants consisting of the employee from each level of position. Leadership style at the Converting Department, PT. IPP, is centered on characteristics of existing leaders with the most dominant leadership style is exploitive-authoritative because it is attached to the top leader. The existing leadership style is not quite ideal to face challenges in the future. For internal organizational communication, patterns occur either downward communication, upward, horizontal and cross-channel.

\section{Introduction}

An organization is established with a specific purpose. The organization's behavior and attitudes influence its ability to achieve its objectives. Therefore, the willingness of members of the organization to manage the resources contained in work units within the organization is essential to achieving goals. Employees in business organizations play a vital role in shaping the organization and display a wide range of responses to a variety of pressures. In reality, an organization's performance is measure by the development of the leadership's ability and the compensation delivers to the employees to achieve the stated organizational objectives. Increasing demands in all forms of change, most companies are attempting to adapt the corporate culture paradigm needed to guarantee the organization's sustainability and gain competitive advantages in the business environment. It is since the current culture is no longer capable of improving the condition that the organization requires. The strengths of the organization's internal and external environments lead to the need for cultural transformation to meet the demands of massive change.

The role of the leader cannot be separated from organizational effectiveness in accomplishing organizational goals. Leadership is the backbone of the organization's development, as it is difficult to attain desired objectives without good leadership. Leadership in a business organization is developed based on an 
established staffing system and career development based on work performance, professional abilities, expertise, skills, and the stability of employees' mental attitudes to adapt to the changes that occur (both inside and outside the organization).

The Converting Department is a work unit that converts semi-finished paper (base paper) into finished paper products. Using a combination of human labor (labor-intensive) and production machines, such as photocopy paper cutting machines (cut size sheeter machine). The Converting Department's performance evaluates by comparing actual production results to the company's previously established targets. KPIs are used to express the objective (Key Performance Indicator). In 2020, the Converting Department has seven key performance indicators (KPIs) to achieve (table 1). Production handed to the warehouse (production results delivered to the warehouse) is the most important target achievement. It is an accumulation of finished paper products distributed to customers. The following is the production performance from 2018 to 2020 , using the production handed to the warehouse as the main KPI.

Table 1. Converting Dept. KPI (2020)

\begin{tabular}{clc}
\hline No & \multicolumn{1}{c}{ KPI items } & Amount \\
\hline 1 & Production (handed to warehouse) & $504,000 \mathrm{~T} / \mathrm{Y}$ \\
2 & Total efficiency & $>50 \%$ \\
3 & Cutsize packing cost & $50 \mathrm{USD} / \mathrm{T}$ \\
4 & Broke/waste & $3 \%$ \\
5 & Spare parts idle and deadstock & USD 0 \\
6 & Customer claim and complain & 8.65 \\
7 & index & LSD 11.5/T
\end{tabular}

Source: Converting Dept. PT. IPP (2021)

The target for 2018 is 480,000 tons, as illustrated in figure 1 , with a production target of 357,228 metric tons (achievement 74.27 percent of the target). Then in 2019, with the same KPI target as in 2018 and a total of 352,140 tons achieved (73.37 percent achievement of the target). As can be observed from the above description, production performance decreased by 0.90 percent in 2019 compared to the previous year. Then, in 2010, the KPI production target was increased to 504,000 tons, compared to previous years. It implies an increase in production, but it is still far below the target.
Converting Department, PT. IPP has made various efforts to increase these resources to provide the maximum contribution. However, the efforts made have not been able to make a significant impact on employee performance. Tasks that cannot complete on time, a lack of coordination and communication between units, and poorly organized employee administration (from the preliminary survey, January - February 2021). These findings were influenced by several variables, including a non-persuasive leadership style, low employee work motivation, improper communication system, and lack of encouragement of the employees in carrying out their responsibilities.

Leaders in command of an organization should preferably utilize a persuasive leadership style that appropriates to the situation and conditions. It will be difficult for leaders who do not adapt their leadership style to establish a conducive and harmonious work environment and climate. Employee performance will suffer because of such circumstances. The communication process enables leaders to carry out their responsibilities and duties. Appropriate information must be communicated to leaders so that they have a basis for decision making and planning, and then these plans communicate to others for implementation.

By evaluating the leadership behaviors and communication patterns that occur in one of the manufacturing industry's firms, this study contributes to the advancement of science, particularly management science. The findings can be utilized as a basis for evaluation and consideration while doing or formulating corrective action, specifically in the area of policy development. Furthermore, research is useful not only in the context of developing theoretical and practical policies, but it can also help improve the performance of company management in terms of implementing leadership practices, as well as establishing and developing communication patterns among relevant parties within the organization. This study aims to overcome literacy gaps and reflect on the most recent issues concerning leadership styles and communication patterns, particularly in manufacturing firms. 


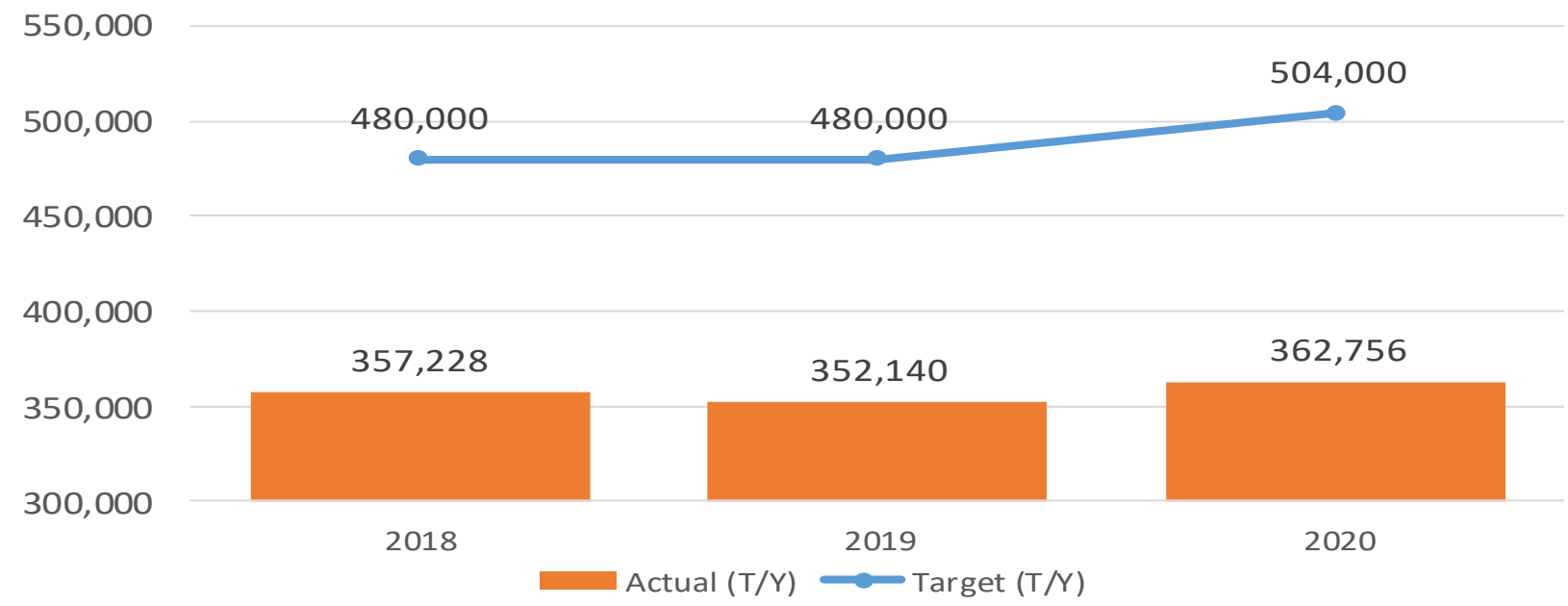

Figure 1. Converting Dept. Target VS Actual (2020) Source: Converting Dept. PT. IPP (2021)

\section{Literature review}

\subsection{Leadership}

According to Robbins and Coulter (2018), leadership is defined as the ability to influence a group toward goal achievement. Terry \& Rue (2015) similar to Robbins \& Coulter mentioned leadership is an activity that involves persuading others to achieve group goals. Tannenbaum, Weschler, and Massarik (in Hersey et al., 2018) define leadership as an interpersonal influence used in a situation and demonstrated through the communication process to attain specified objectives.

\subsubsection{Situational (Contingency / Situational Theory}

This theory states that before utilizing a specific leadership style, leaders need to understand their behavior, the behavior of their subordinates, and the environment. This approach necessitates the leaders able to identify human interactions (Konopaske, Ivancevich, \& Matteson, 2017).

\subsubsection{Leadership Style}

In Pace \& Faules (2015), McGregor identifies two categories of assumptions that leaders make about other individuals. Theory $\mathrm{X}$ and Theory $\mathrm{Y}$ are the two sorts of assumptions. A leader, according to Theory $\mathrm{X}$, will regard individuals as instruments of production, motivated by fear of punishment.

Leaders that have this perspective on employees are more likely to keep control of them, set and enforce strict regulations, and utilize the threat of punishment to motivate them.
Leaders in Theory $\mathrm{Y}$ assume that employees have a variety of needs. Leaders believe it is their responsibility to organize and manage so the organization and its employees may reach their objectives. Leaders believe that individual and organizational goals may coexist in this approach. Some individual and firm objectives may be at odds. Managers who adopt Theory $\mathrm{Y}$ assumptions, on the other hand, collaborate with employees to achieve organizational goals, encourage employee participation in decision-making, and strive for improvement.

\subsubsection{Leadership Style}

Likert mentioned (in Luthans, 2014) managerial styles based on an analysis of eight managerial variables: 1) leadership, 2) motivation, 3) communication, 4) interaction, 5) decision making, 6) goal setting, 7) control, and 8) performance. The management styles divided into four categories by Likert (in Ganos \& Gallo, 2013):

1) Exploitative-authoritative, this style is based on the assumptions of Theory $\mathrm{X}$. Employees are given guidance and close supervision by their leaders, who believe that the best way to inspire them is to use fear, threats, and punishment. Superiors and subordinates have minimum interaction. All decisions come from the top, and communication downwards solely contains instructions and orders.

2) Benevolent-authoritative, this style is mainly authoritarian but encourages upward communication to share opinions and raise 
complaints from subordinates. However, the interaction between the levels in the organization is performing through official channels. Communication is rarely open and straightforward.

3) Consultative, this style involves a frequent interaction on a personal to moderate level, between superiors and subordinates in the organization. Information goes both up and down, but with little emphasis on ideas originating from Superiors. Superiors give great confidence in subordinates, even though this is not a necessity.

4) Collaborative, this style is very supportive, intending to make the organization more effective through meaningful employee involvement. Controls are exercised at every level as the information travels in all directions. People interact openly, honestly, and without fear of punishment.

\subsection{Organizational Communication Pattern}

From a subjective standpoint, organizational communication is the process of giving meaning to organizational interactions. The actual organizational behavior occurs and how individuals involved in the communication process perceive and assign meaning. Communication also defines as the transmission and interpretation of messages among communication units within an organization. An organization consists of communication units arranged in a hierarchical order and performs functions in a given environment (Pace \& Faules, 2015).

\subsubsection{The Linking Pin Model Theory}

The linking pin model theory developed by Likert (in Hicks \& Goronzy, 2017), tends to emphasize and assist what should happen in classical and bureaucratic institutions. However, the superior-subordinate hierarchical pattern frequently promotes downward communication while inhibiting upward and horizontal communication. The slowness of collective action, which is a characteristic of a pin-pin structure organization, must balance against the positive benefits of participation, which include increased employee dedication and more open communication.

\subsubsection{Organizational Communication Patterns Categories}

Organizational communication patterns divided into four categories by Pace \& Faules (2015): (1) Downward communication. Information travels from higher to those of lower authority in a downward communication system inside an organization. According to Miner (2014), superiors often transmit five types of information to subordinates: information about how to do work, information on the rationale for doing work, information about organizational policies and procedures, information regarding employee performance, and information to develop a sense of having a duty (sense of mission). (2) Upward communication. In an organization, upward communication flows information from lower levels (subordinates) to higher levels (superiors). Each subordinate can have a valid reason for requesting or providing information to someone with higher authority. The essence of upward communication is a request or comment addressed to someone with greater or inferior authority. Horizontal communication. Horizontal communication is the exchange of information between coworkers in the same work unit. The work unit includes individuals who worked at the same level of authority in the organization and have the same superiors. (4) Crosschannel communication. In most organizations, there are needs for employees to share information across the functional boundaries of individuals who are neither superior nor subordinate. They do not have the line authority to direct the people they communicate with and promote their ideas.

\subsection{Framework}

As indicated in figure 2 , this study is designed in a framework used by the authors to meet the research objectives. In qualitative research, some notions should further state based on the framework (figure 2) to achieve reliability. It developed to concentrate the study on specific phenomena related to the symptoms observed, allowing for precise analysis and understanding of the study's conclusions. As a result, the author will implement the following concepts: 


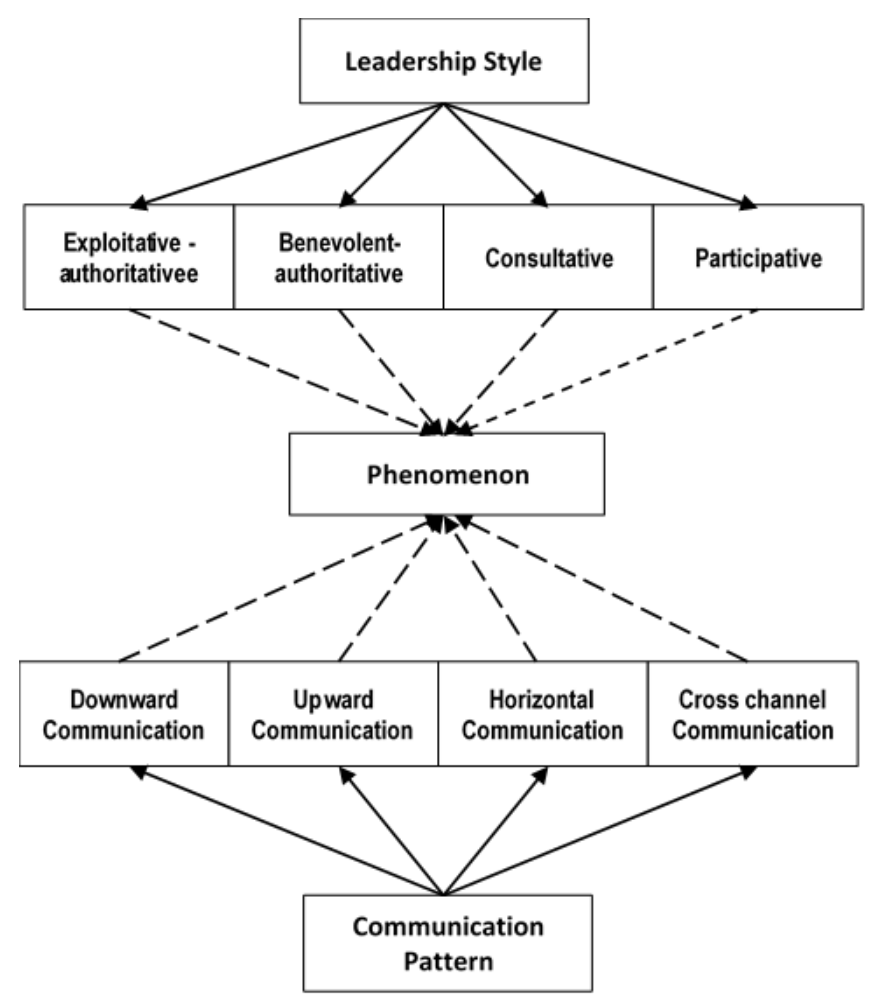

Figure 2. Research Framework

Source: Likert in Luthans (2014) \& Pace \& Faules (2015)

1) The leadership style is concerned with relationships (positive relationships and involving others in decision-making in the context of task management) (completing things and achieving organizational goals).

2) A communication pattern is a set of conditions for activities and interactions that move continuously and dynamically and as a persistent and continuous method of constructing and interpreting communications. This process is repeat and altered regularly.

\section{Research method}

The descriptive qualitative research technique was employed to achieve the study's goals. The qualitative descriptive approach is considered suitable for observing and analyzing social phenomena. According to Creswell (2016), qualitative research is an inquiry method about understanding based on several methodological techniques. The researcher constructs a comprehensive, holistic picture, examines words, reports detailing the perspectives of speakers, and performs a study in a natural context.

\subsection{Informant}

People who are willing to contribute concepts and information and serve as a resource for questions are known as key informants. As a result, when gathering data, researchers begin with key informants to obtain a thorough and comprehensive picture of the issues encountered (Martha \& Kresno, 2016). The key informant is considered appropriate and meets the author's requirements to provide information following the research objectives. 356 employees are working in the Converting Department (data per January 1, 2021). In determining which respondents to participate as informants, representatives are selected from each level of position in the Converting organizational structure and considered represent each work unit in the Converting Department's production process.

The leadership structure in the Converting Department organization consists of a General Manager, Manager, Shift Leader, Group Leader. The object of research is limited to the General Manager and Manager levels. As for the Shift Leader, Group Leader, and Machine operator as informants.

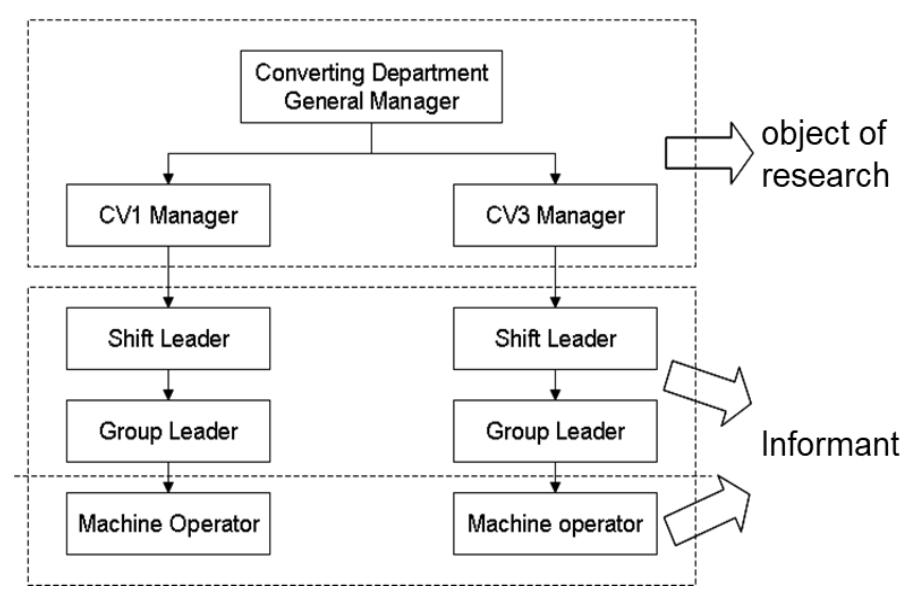

Figure 3. Converting Department Structure Source: Converting Dept. (2021)

Informants from each level (shift leader, group leader, and machine operator) are modified to the study's needs, rather than taken as a whole and employed as informants.

\subsection{Data Source}

Informants from each level (shift leader, group leader, and machine operator) customized to the study's needs rather than collected as a whole and employed as informants. 


\subsection{Data Collection Method}

There are two approaches used in data collection to support this research using observation and supported by unstructured interviews. The leadership style and communication patterns that occur in the Converting Department, PT. IPP, were studied through observation and unstructured interviews.

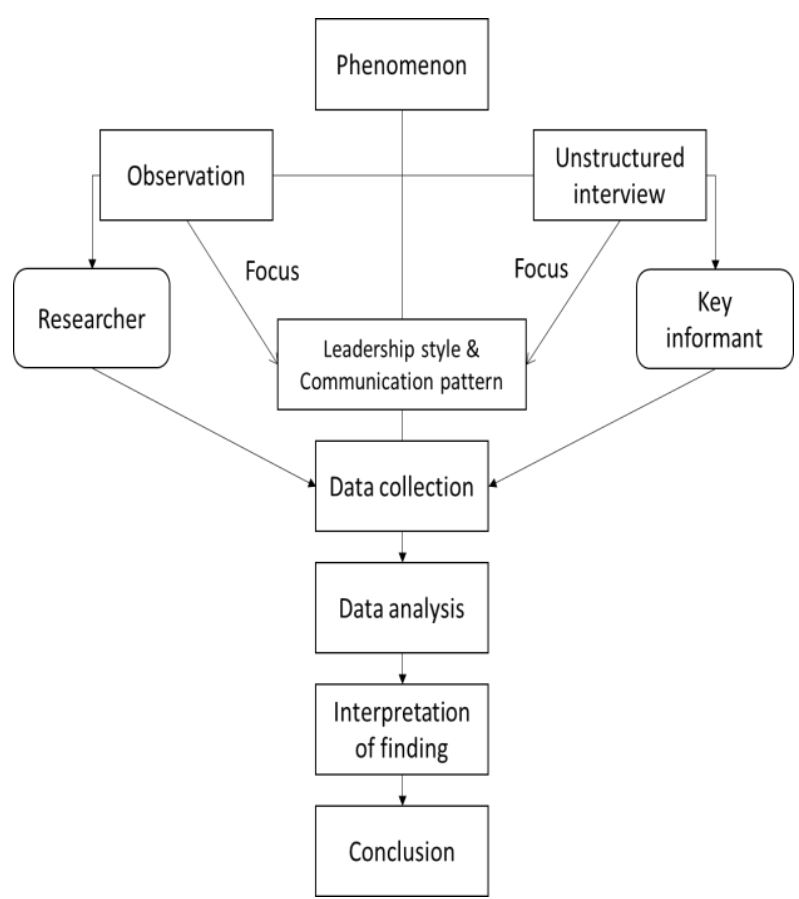

Figure 4. Data collection method

\subsection{Data Analysis Technique}

To analyze the data, the author adopts Miles \& Huberman's interactive model data analysis (in Miles, Huberman, \& Saldana, 2019), a data analysis technique that describes the interactive nature of the data collection. as seen in figure 5, data collection, data reduction, data display, and drawing conclusions or data verification are the several forms of analysis activities. In general, (1) record all phenomena found in the field either through observation, interviews, or documentation; (2) review the records of the results observations, interviews, and documentation studies, and separate data that is considered important from data that is considered unimportant; (3) repeat this work to check for possible errors in classification; and (4) write the final analysis in the form of a research report.

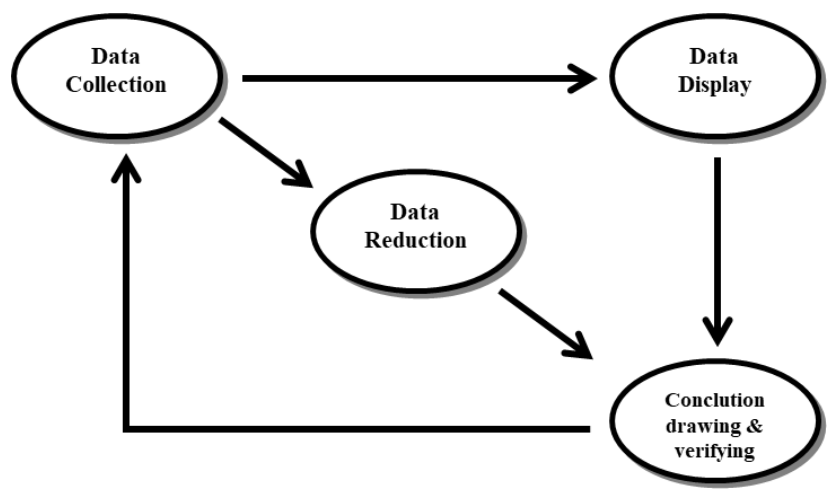

Figure 5. Interactive model data analysis Source: Miles \& Huberman (in Miles, Huberman, \& Saldana, 2019)

\subsection{Data Validity Techniques (Validation and Accuracy)}

Qualitative data validity checking techniques used consisted of: participation extension, finding data similarity cycles, observation persistence, triangulation, checking through discussion, checking through team members, adequacy of references, detailed descriptions, and auditing (Bungin, 2017). In this research, data validity checking techniques consist of participation extension, observation persistence, triangulation, checking through discussion, reference adequacy, detailed description, and auditing.

\section{Results and Discussion}

\subsection{Informant characteristics}

The data analysis and discussion begin with a description of the informants' characteristics. The number of informants questioned to support the findings of the observations was 22 . All of the informants are full-time workers of PT. IPP's Converting Department.

Table 2. Characteristics of informants $(\mathrm{N}=22)$

\begin{tabular}{llcc}
\hline \multicolumn{2}{c}{ Characteristics of informants } & Freq. & \% \\
\hline Gender: & Male & 18 & 81.82 \\
Age: & Female & 4 & 18.18 \\
& $<$ 25 years & 2 & 9.09 \\
& 25 - 35 years & 15 & 68.19 \\
& 36 - -45 years & 4 & 18.19 \\
Education: & $>$ 45 years & 1 & 4.55 \\
& High school & 18 & 81.82 \\
& Diploma & 1 & 4.55 \\
Years of service: & Undergraduate & 3 & 13.64 \\
& $10-15$ years & 4 & 18.19 \\
& $15-20$ years & 17 & 77.28 \\
& $>20$ years & 1 & 4.55 \\
& 0 & 0 \\
\hline
\end{tabular}




\begin{tabular}{|c|c|c|c|}
\hline Charact & eristics of informants & Freq. & $\%$ \\
\hline \multirow[t]{3}{*}{ Position: } & Machine Operator & 12 & 54.55 \\
\hline & Group Leader & 7 & 31.82 \\
\hline & Shift Leader/Assistant & 3 & 13.64 \\
\hline
\end{tabular}

Based on table 2, the number of male informants was higher than the number of females. The majority of informants are between the ages of 25 to 45 . The informants' average educational level is high school. The majority of informants have employed for 10 to 15 years and the most informants are machine operator level.

\subsection{Leadership Style in Converting Department}

The Converting Department manages regularly by a General Manager and is assisted by four managers assigned in two separate units.

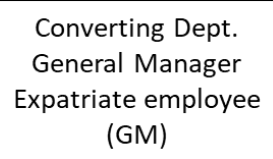

\begin{tabular}{|c|}
\hline $\begin{array}{c}\text { Converting 1 } \\
\text { Section }\end{array}$ \\
\hline $\begin{array}{c}\text { Expatriate employee } \\
\text { (MG 1.1) }\end{array}$ \\
\hline
\end{tabular}

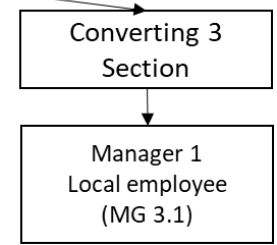

Figure 6. The Converting Department's Management

Source: Converting Dept. (2021)

The general manager (hence referred to as GM) is a Taiwanese expatriate who has worked at PT. IPP for 21 years. GM appears to be authoritarian and favors a sanctioned approach in carrying out its leadership role. If there is a discrepancy in subordinates' task performance, before even referring to the explanation of the person who made the mistake, the order to punish those involved must be implemented without prior review or evaluation of the weight/level of mistake. One of the informants mentioned that he once made the mistake of pushing a paper roll with his feet. The GM saw this, started screaming and saying things that no one could understand because it was a foreign language. However, it was not followed by attempts to impose administrative sanctions, as is often the case. It was also confirmed by several other informants who had experienced the same incident but in different conditions and cases.

In performing management activities, GMs seldom employ standard management tools such as SWOT (Strengths, Weaknesses, Opportunities, and Threats), POAC (Planning, Organizing, Actuating, and Controlling), and PDCA (Plan, Do, Check and Action). In the workplace, his leadership is more reactive and situational. In this scenario, action is taken in resolving a situation as soon as possible without any further planning. The attitude of discipline, responsibility, and a strong commitment to the firm, on the other hand, should be exemplified. GM has a habit of arriving early to work, working outside of office hours, and staying late on holidays. It demonstrates his concern for the production process's continuity and for resolving any production issues immediately.

The involvement of the GM in motivating their subordinates directly and face-to-face is limited due to language barriers. There is no need to develop emotional ties with his subordinates. Even if efforts to motivate subordinates directly / face-to-face are limited, this does not mean that efforts to motivate subordinates indirectly are missing. It is demonstrated by the conducting of index competition activities, in which these activities compete between employees against one another to achieve production targets.

According to the above description, GM, as the top leader of the Converting Department, adopts a leadership style that emphasizes fear (with the possibility of implementing punishment) to encourage employees directly and is authoritarian in every decision/policy making. He takes an authoritative approach to persuade subordinates to follow commands and instructions. This type of leadership is exploitative-authoritarian leadership style.

The Converting Section \#1 has an expatriate manager (hereafter referred to as MG1.1) from Taiwan who has been with PT IPP since 2014. MG 1.1 has a different approach from GM, in that MG 1.1 is willing to listen even while receiving reasonable arguments from subordinates. When MG 1.1 expressed its opinion, an attempt was made to 
impose it by elevating the tone of the voice to an angry pitch. Since MG 1.1 had no prior experience with the Converting production process, it was necessary for MG 1.1 to always solicit opinions from everyone who was directly involved in the process.

If the production process is abnormal during the daily operational cycle, MG 1.1 will move fast. His arguments tend to cast doubt on his subordinates' ability to perform the tasks. On the positive side, MG 1.1 always provides alternative solutions for solving problems, which are then reviewed with subordinates who are more knowledgeable about operational and technical conditions in the field. Decisions are made based on feedback from subordinates and interactions with other employees categorized as experts, but the outcomes of analysis and opinions from $\mathrm{MG}$ 1.1 are still prioritized.

MG 1.1's leadership style involves encouraging subordinates to share information through discussion and promoting small meeting activities. However, it is critical to underline the ideas from MG 1.1. By prioritizing elements of logical thinking, MG 1.1 , on the other hand, frequently provides transfer of work insights to subordinates. Arguments that did not make sense were brushed aside in favor of new ones that he thought were far more plausible. Although MG 1.1's leadership style enables subordinates to express their thoughts in the form of suggestions and complaints, his opinions must inevitably take precedence. This leadership style is closer to the nature of the benevolentauthoritative.

A local employee manages converting \#3 section (hereinafter referred to as MG 3.1). He has a lot of experience with the Converting process since he has worked in it since he first started working. His career has been quite successful, with him rising through the ranks to become a manager within only 12 years. MG 3.1 emphasizes a persuasive approach in persuading subordinates to perform an activity following what intended while maintaining his identity as a leader in conducting managerial functions and responsibilities. Directions communicate to subordinate clearly and concisely. Communication is more transparent.
However, not all aspects of production are open discussed.

MG 3.1 encourages subordinates to raise issues that arise during the production process. Discussions are held to determine the root cause of the problem as a foundation for identifying the best solution to resolve the issues. MG 3.1 places more emphasis on ideas that are acceptable to all. Although some agendas in the field are not completely entrusted to his subordinates.

MG 3.1 made decisions relying on information provided by subordinates. However, as the condition in the production process changes, the decision could become inconsistent. Subordinates are frequently confused by this circumstance. MG 3.1's leadership style is more conservative towards subordinates and does not leave personal approaches to accept ideas conveyed by subordinates, even though it still prioritizes ideas originating from MG 3.1. It is combined with giving subordinates the confidence to improvise in solving a process problem, differentiates MG 3.1 as a consultative leader.

\subsection{Converting Department Organizational Communication Patterns}

Organizational communication patterns that occur in the Converting Department's production process activities are described through an approach to the elements of downward communication, upward communication, horizontal communication, and cross-channel communication.

\subsubsection{Downward Communication}

As illustrated in Figure 7, formal communication occurs from the highest level to the lowest level. The general manager communicates directly with the manager $\left(\begin{array}{ll}1 & 2\end{array}\right)$ on several occasions, and information is also communicated directly to subordinates below one level, notably the shift leader (1 3). The importance of the information varies depending on whether it delivers to the managers or the shift leader. Unless there is a situation where the manager is not present, meanwhile the shift leader is in the top position in the location. Due to the high level of urgency, the general manager's directions must follow up immediately. 
In downward communication, the general manager conveys verbal (instructions/orders, sanctions, information on matters such as information \& production planning, policy changes, information related to employee performance), product development, and quality problems to the managers $(1 \rightarrow 2)$.

The communication pattern between the general manager and the shift leader $(1 \rightarrow 3)$ is primarily oral and more centered on operational details within the scope of the shift, which is under the shift leader's responsibility. Problems, ideas, abnormalities, engine modifications, and other productionrelated issues communicate directly to the shift leader on duty at the time. Although the general manager rarely issues written directions, he does provide general information, which is only available in the form of announcements posted in the shift leader's room. Every day, the manager will rediscuss this information in a routine meeting.

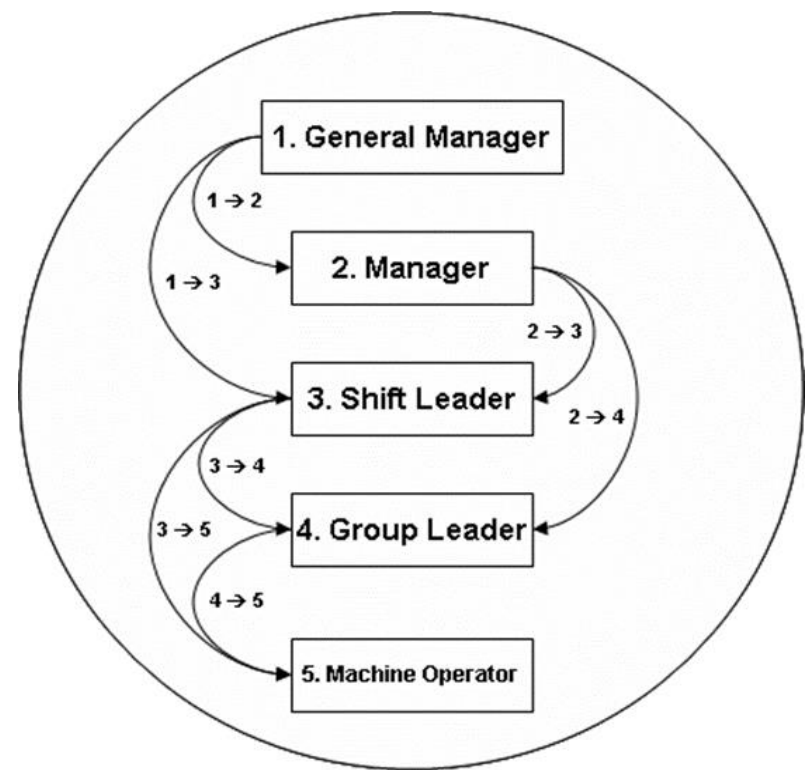

Figure 7. Downward communication patterns in the Converting Department.

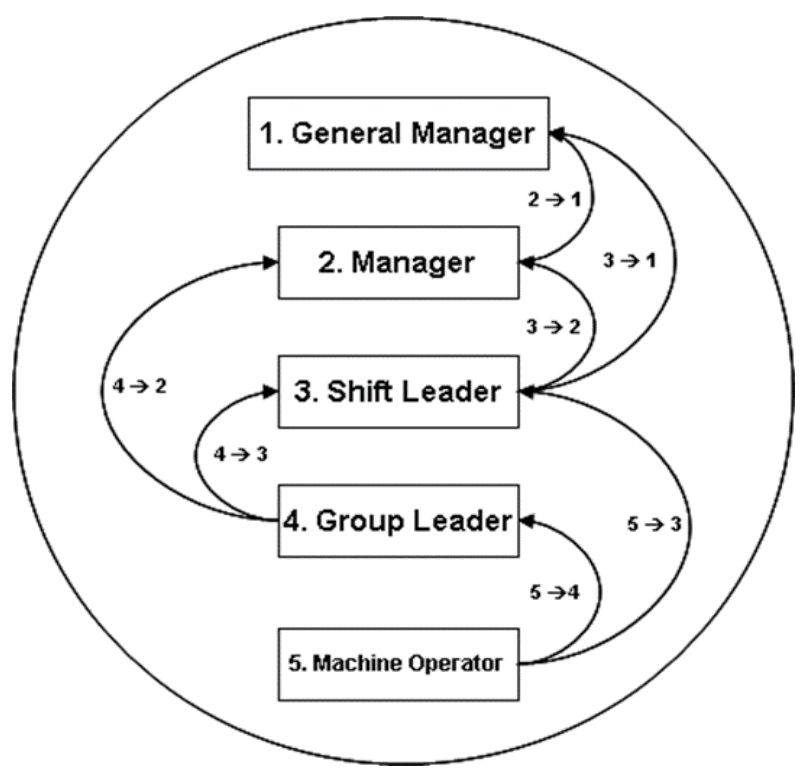

Figure 8. Upward communication patterns in the Converting Department.

The information received by the manager from the general manager $(1 \rightarrow 2)$ is then communicated to the shift leader $(2 \rightarrow 3)$, after a filtering process by the manager. Not all information comes from the general manager, who then passes it along to the shift leader and group leader $(2 \rightarrow 4)$ based on the level of urgency of the information. Managers primarily communicate orally with shift leaders $(2 \rightarrow 3)$ and group leaders $(2 \rightarrow 4)$. Motivation/guidance and target achievement, production operations, production administration, corrective and preventive maintenance and electrical activities, product quality problems, human resources, packing materials, production planning, equipment cleanliness, and environmental hygiene are all examples of information or instructions are conveyed. 


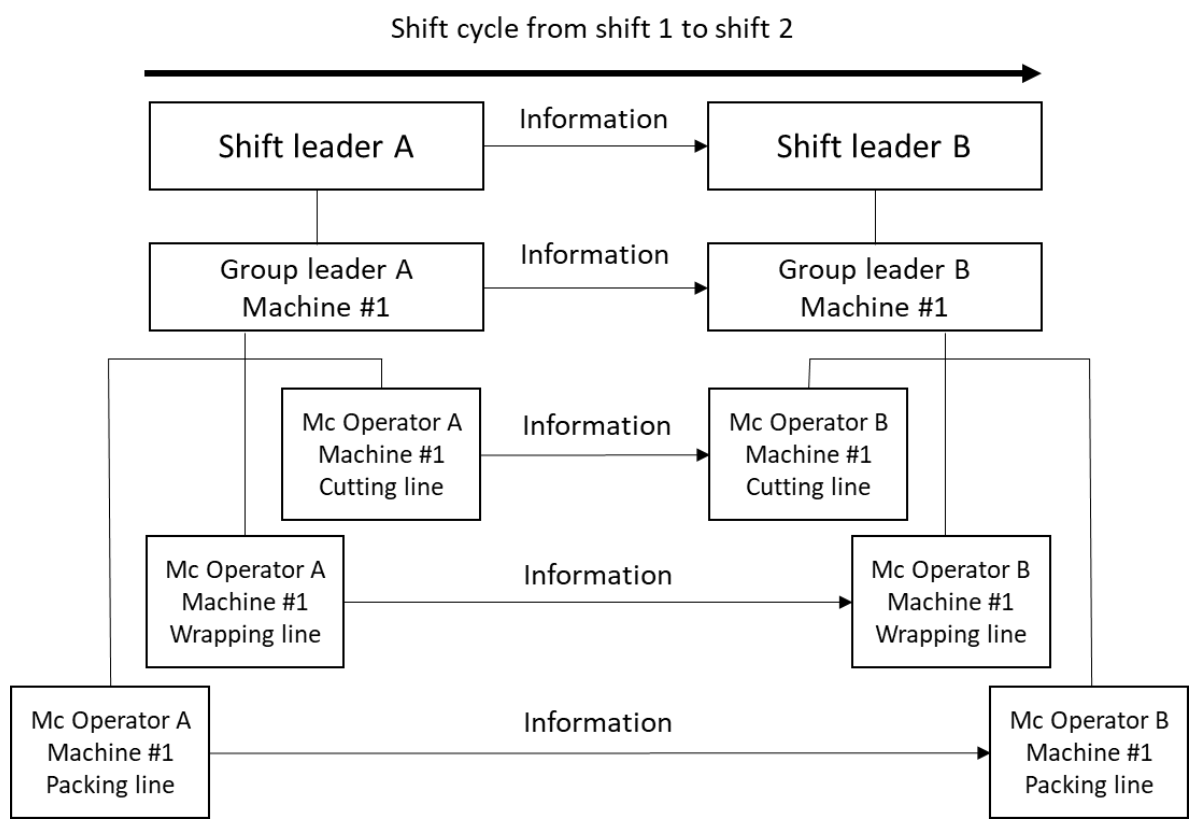

Figure 9. The Information exchange cycle at work shift changes

The next flow of communication is from the shift leader to the group leader $(3 \rightarrow 4)$ and then from the shift leader to the machine operator $(3 \rightarrow 5)$. The communication flow between the shift leader and the group leader $(3 \rightarrow 4)$ is nearly identical. The difference is the scope of responsibility between the shift leader, who is in charge of several machines, and the group leader, which is limited to machine operational arrangements, quality problems, and human resource allocation. It also covers topics such as how to operate machines, how to resolve quality problems, motivation and guidance, equipment cleanliness, and environmental cleanliness group leaders to machine operators. It is a more technical aspect of the daily operations of machines, such as operational work instructions and coaching of individuals under coordination, for the flow of information from group leaders to machine operators $(4 \rightarrow 5)$.

\subsubsection{Upward Communication}

The downward communication pattern is the opposite of the upward communication pattern. Complaints, difficulties, and problems encountered in the workplace, as well as requests for information, are the most common forms of communication. The upward communication patterns that occur in the Converting Department, as if mentioned in figure 8 . Numerous daily operational problems are encountered in the production process, such as machine operation, difficulties in overcoming machine damage, interactions between machine operators, and other obstacles that must overcome yet require higher authorities' attention and assistance. For example, if a machine malfunctions, the machine operator will fix the problem to the best of their abilities. If the problem cannot be resolved, the next step is to notify the group leader $(5 \rightarrow 4)$ to take necessary action, such as joint corrective action (between the group leader and the machine operator) or other decisions. If the problem is unsolved, information will forward to higher levels, such as shift leader, manager, and general manager. Even if the problem disrupts the smooth running of production, it is put forward to the director level. 
The shift leader informs the managers $(3 \rightarrow 2)$ on the current situation and conditions in the production process. Deliver production results, troubleshooting, equipment, and between shifts (primarily at each shift change). Figure 9 illustrates horizontal communication.

As shown in Figure 9, while changing from the previous shift (A) to the next shift

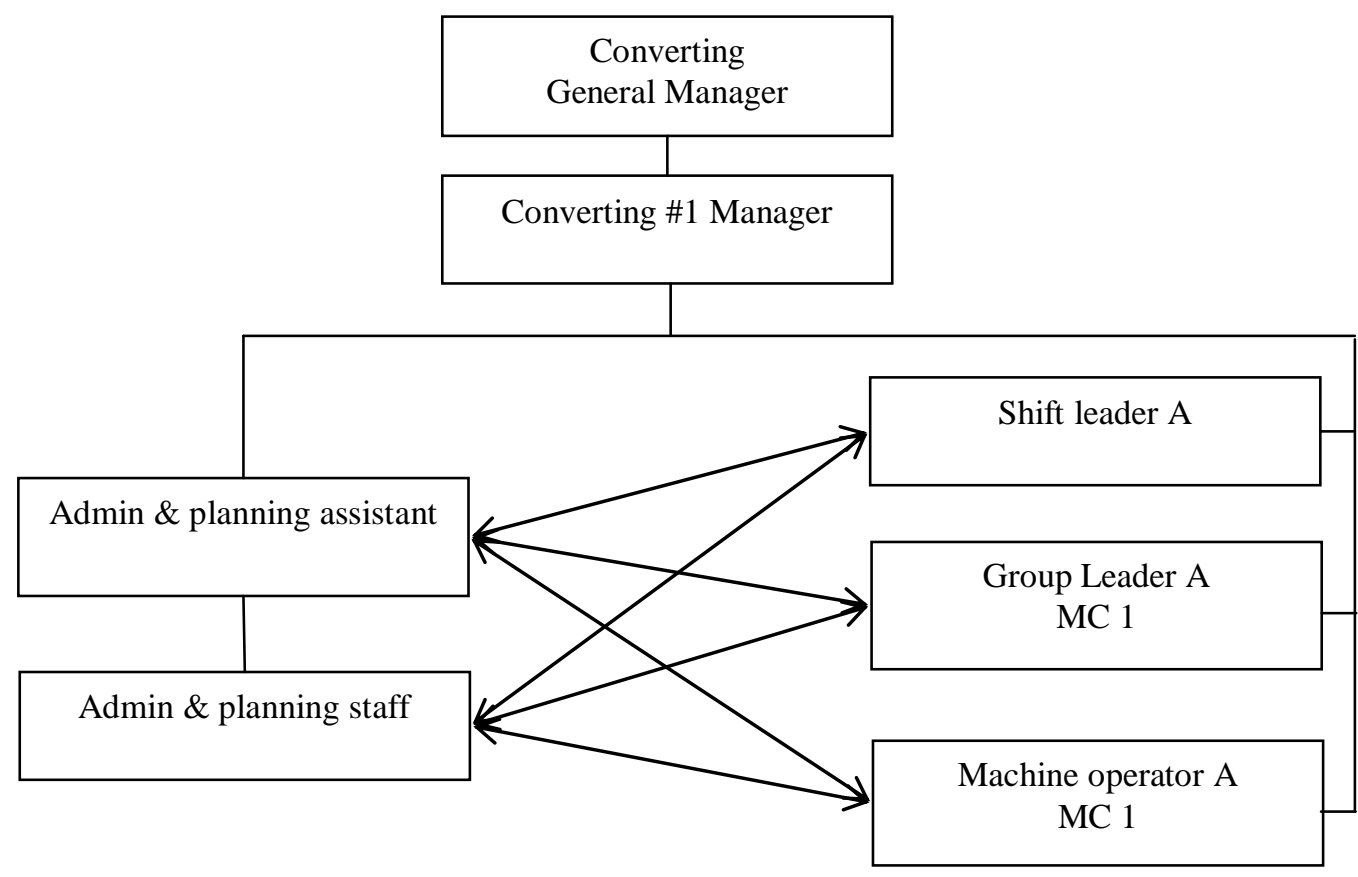

Figure 10. Cross-channel communication between the administration and planning unit and the production unit in the Converting Section.

environmental conditions, quality abnormalities, worker issue, and other issues during the production cycle. The purpose is that the manager can provide direction and make the decisions in dealing with the situation. The manager informs the general manager of the status of the production process $(2 \rightarrow 1)$. The general manager is only informed about severe problems, and the production process requires special attention from higher authorities. The manager may also approach the general manager's approval of a program or policy implemented in the production section.

\subsubsection{Horizontal Communication}

Horizontal communication between shifts and machine units is an essential need. The converting process is a $24 / 7$ production process. The top management has given orders for the production machines to keep running without stopping. While in operation, the machine must stop due to a roll change or a machine breakdown. Information on engine speed, engine failure, quality issues, and other technical matters must be communicated
(B), the previous shift requires providing information to the next shift leader about the current situation and conditions in the production field. The previous shift's MC \# 1 group leader must share information with the next MC \#1 group leader. To maintain machine production continuity, each machine operator for cutting, wrapping, and packing performs the same procedures.

\subsubsection{Cross-channel Communication}

Converting is a manufacturing process that also involves planning and administration. The administration unit, directly under the manager's supervision, is responsible for planning and administration. The administration and production planning unit is responsible facilitates production activities. The administration unit, like the production line, is a functional part of an organization. As shown in figure 10 , the cross-channel communication interaction between the administration unit and the production unit (Similar between Converting \#1 and Converting \#3). 
Cross-channel communication between the administration and the production unit performs regardless of the position level, as shown in figure 10. Production personnel can contact the administration and planning unit directly for administrative functions related to operations, such as procurement of packing materials and confirmation of orders to fulfill. Furthermore, the administration and planning unit can directly contact for the procurement of employee facilities such as PPE (Personal Protective Equipment) and work uniforms.

\section{Conclusion \\ Conclusion}

The implemented leadership styles, on several occasions, are generally ineffective in influencing and providing understanding towards subordinates to work at their maximum potential to meet organizational goals. The current organizational communication pattern has been in place for more than a period, with numerous adaptations made in response to changes that occur over time. The leadership elements (general manager and manager) leadership styles are different from one another. The prevailing perception is that leaders view their subordinates as "production tools", must perform efficiently and effectively to meet their objectives. The dominant leadership style of the highest leadership, notably the general manager act as the absolute ruler (exploitativeauthoritative). The interactions that occur are limited to superior-subordinate relationships.

As a result, Theory $\mathrm{X}$ becomes more prominent than Theory $\mathrm{Y}$ (since Theory $\mathrm{X}$ is attached to the general manager's leadership style as the Converting Department's highest leader). As a formal organization with a clear organizational hierarchy, all decisions must refer to the highest leadership's decisions and policies. The implementation adapts to the managers' assumptions and leadership styles under the coordination of the general manager, for application in the production field.

Organizational communication patterns: downward, upward, horizontal, and crosschannel communication have patterns and information flows. In general, the difference lies in the interests, differences in the media used, the scope of information conveyed, and the type of information to the responses generated, by both leaders and subordinates. The superior-subordinate hierarchical communication pattern in the Converting Department is compatible with Likert's linking pin model theory, notably in the superiorsubordinate hierarchical communication pattern, which regularly pushes downward communication while hindering upward and horizontal communication.

Leaders change the existing paradigm, in which subordinates are viewed simply as production tools, to become subordinates with personality and ideas that develop with time, contribute to the production process, and demonstrate their potential. A leader/manager must have sufficient knowledge of production processes, both by technical and administration, to provide policies effectively and efficiently in planning, organizing, implementing activities, and supervision. Develop communication patterns by removing vertical and horizontal communication barriers and empowering subordinates to optimize information flow.

The following are expected implications from the study: (1) For scientists of management science who are interested in exploring the same topic and can be used as a comparison, notably in manufacturing firms. (2) In practice, this study can help to clarify the leadership style and communication patterns of employees working together to meet firm/organizational goals in manufacturing firms.

Several limitations encountered while conducting this study: (1) This study only examines one company's leadership style and organizational communication patterns, and it cannot be generalized to other firms. (2) Although the study included a small number of participants, it is considered to be representative of the firm's entire population.

\section{References}

Bungin, B. (2017). Penelitian Kualitatif: Komunikasi, Ekonomi, Kebijakan Publik, dan Ilmu Sosial Lainnya. jakarta: Kencana.

Creswell, J. W. (2016). Research Design: Pendekatan Metode Kualitatif, Kuantitatif dan Campuran (4th ed.). Yogyakarta: Pustaka Belajar. 
Ganos, J., \& Gallo, P. (2013). Model for Leadership Style Evaluation. Management, 18(2), 157-168.

Hersey, P., Blanchard, K. H., \& Johnson, D. E. (2018). Management of Organizational Behavior (9th ed.). New Jersey: Prentice Hall.

Hicks, H. G., \& Goronzy, F. (2017). On Methodology In The Study Of Management And Organization. Academy of Management Journal, 10(4). https://doi.org/https://doi.org/10.5465/255 270

Konopaske, R., Ivancevich, J. ., \& Matteson, M. . (2017). Organizational behavior and management. New York: McGraw-Hill Higher Education.

Luthans, F. (2014). Organizational Behavior. In The McGraw-Hill/Irwin (14th ed.). https://doi.org/10.5005/jp/books/10358_2 3

Martha, E., \& Kresno, S. (2016). Metodologi Penelitian Kualitatif dan Kuantitatif dalam Bidang Kesehatan. Jakarta: Raja Grafindo Persada.

Miles, M. B., Huberman, A. M., \& Saldana, J. (2019). Qualitative Data Analysis: A Methods Sourcebook (4th ed.). Arizona: SAGE Publications, Inc.

Miner, J. B. (2014). Organizational Behavior 2. New York: Routledge.

Pace, R., \& Faules. (2015). Komunikasi Organisasi: Strategi Meningkatkan Kinerja Perusahaan. Bandung: PT. Remaja Rosdakarya.

Robbins, S. P., \& Coulter, M. (2018). Management (14th ed.). New York: Pearson.

Terry, G. R., \& Rue, L. W. (2015). DasarDasar Manajemen (16th ed.). jakarta: Bumi Aksara. 